\title{
Työelämätaitojen kehittämisen mallit korkeakoulutuksessa
}

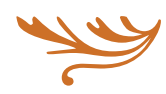

\begin{abstract}
Yliopistojen sisällä käydään keskustelua humboltilaisen sivistysyliopistoihanteen
ja muuttuneiden yhteiskuntasuhteiden yhteensopivuudesta. Haastajiksi ovat

nousseet työvoimakompetenssit. Artikkelin kirjoittajat erottavat tutkimissaan

korkeakouluissa kolme työelämäntaitojen kehittämisen mallia, jotka he nimeävät spesialistimalliksi, integratiiviseksi malliksi ja verkostoituneen kulttuurin malliksi.
\end{abstract}

ARTIKKELI PERUSTUU tutkimukseen, jossa on analysoitu korkeakoulujen toimintatapoja erityisesti opiskelijoiden työelämätaitojen kehittämisen näkökulmasta. Vaikka korkeakoulututkimus on eriytynyt omaksi tieteenalakseen, tässä yhteydessä kyseinen tutkimusteema nähdään osana aikuiskasvatusta ja aikuiskasvatustiedettä, koska tämä tieteenala kohdistuu aikuisen oppimisen ja koulutuksen kysymyksiin (Collin \& Paloniemi 2007) ja koska korkeakoulujen opiskelijat ovat aikuisiässä.

Työelämän nopeat muutokset, globalisaatio ja tietoyhteiskuntakehitys ovat johtaneet siihen, että koulutusjärjestelmään kohdistetaan entistä suurempia odotuksia. Samoista syistä korkeakoulutuksen toimintaympäristöt ovat muuttuneet kompleksisiksi. Euroopan Unionin linjaukset korostavat kestävää talouskasvua, työllisyyttä, entistä parempien työpaikkojen luomista sekä osaamisen ja innovoinnin tukemista (ks. KOM 2005). Korkeakoulutuksessa näitä tavoitteita pyritään Euroopassa viemään eteenpäin yhtenäisen korkeakoulutusalueen avulla Bologna- prosessina tunnetun hallitusten välisen yhteistyön kautta (ks. http://www.ond.vlaanderen.be/hogeronderwijs/bologna/documents/).

Samanaikaisesti yliopistojen sisällä on käyty keskustelua humboldtilaisen sivistysyliopistoihanteen ja uudenlaisen yhteiskuntasuhteen yhteensopivuudesta. Näissä keskusteluissa on tuotu esiin, että korkeakoulut eivät vain passiivisesti seuraa ympäristönsä kehitystä vaan vaikuttavat aktiivisina yhteiskunnan muutos- ja kehitysvoimana sekä tavoilla, jotka turvaavat sekä yhteiskunnan kehitystä, että korkeakoulujen omia toimintaedellytyksiä. (Niiniluoto 2011). Esimerkiksi tutkiva oppiminen (Hakkarainen, Lonka \& Lipponen 2004) ja integratiivinen pedagogiikka (Tynjälä 2008, 2010) voidaan nähdä humboldtilaisen ihanteen valossa teorian ja käytännön, tutkimuksen ja opetuksen yhteytenä. Jatkumona teorian ja käytännön yhdistävälle oppimiselle korkeakouluissa Niiniluoto (2011) visioi tutkivan työskentelyn kehityskulkua työpaikoilla. 
Nopean yhteiskunnallisen muutoksen seurauksena Euroopassa ja myös muualla maailmassa on alettu kiinnittää entistä enemmän huomiota niihin kompetensseihin, joita koulutusjärjestelmä tuottaa. Yhtenä esimerkkinä on OECD:n 2000-luvun vaihteessa käynnistämä DeSeCo-projekti (Definition and Selection of Competences) (Rychen \& Salganik 2003), jossa määritettiin kaikille kansalaisille keskeisiä osaamisalueita toisaalta yksikön menestyksellisen elämän, toisaalta hyvin toimivan yhteiskunnan kannalta. Projekti nosti esiin kolme keskeistä kansalaistaitoa: 1) toimiminen vuorovaikutuksessa erilaisissa ryhmissä, 2) toimiminen autonomisesti ja 3) erilaisten välineiden vuorovaikutuksellinen käyttö, sisältäen a) kielelliset, symboliset ja tekstuaaliset välineet, b) tiedon ja informaation käytön sekä c) teknologian vuorovaikutuksellisen käytön. EU:n tasolla eurooppalainen tutkintojen viitekehys, EQF (European Qualification Framework 2008), puolestaan määrittelee eri koulutusasteilla tuotettavat tiedot, taidot ja pätevyyden. Suomessa EQF:n pohjalta on muodostettu tutkintojen ja muun osaamisen kansallinen viitekehys (OPM 2009).

Vastaavanlaisia kehityskulkuja liittyy myös spesifistiin korkea-asteen koulutukseen. Esimerkiksi eurooppalaisen korkeakoulualueen kehittäminen on nostanut esiin keskustelun oppimistuloksista ja niiden määrittelyistä. Yhtenä esimerkkinä ovat Dublin descriptors, jotka kuvaavat eritasoisten korkeakoulututkintojen tuottamia valmiuksia. Kuvaukset on tehty seuraaville osaamisalueille: 1) tiedot ja ymmärtäminen, 2) tiedon ja ymmärryksen soveltaminen, 3) päätöksenteko- ja arviointikyky 4) kommunikaatiotaidot ja 5) oppimistaidot (Framework for Qualifications... 2005).

Useiden tutkimusten mukaan korkeakouluista valmistuneet ovat kokeneet, ettei koulutus ole antanut riittäviä valmiuksia ja taitoja, joita työelämässä tarvitaan (Crebert ym. 2004; Murtonen ym. 2008; Stenström 2006; Teicler 2007; Tynjälä ym. 2006). Useissa maissa kansallisessa koulutuspolitiikassa onkin koulutuksen työelämäsuhde ja opiskelijoiden työelämävalmiuksien tukeminen nostettu keskeiseksi kehittämiskohteeksi. Suomen edellisen hallituksen vielä (tätä kirjoitettaessa) voimassa olevassa Koulu- tuksen ja tutkimuksen kehittämissuunnitelmassa 2007-2012 todetaan seuraavaa:

"Korkeakoulujen ja työelämän vuorovaikutusta vahvistetaan. Tavoitteena on, että opiskelijat jo opintojensa aikana voivat orientoitua tuleviin työtehtäviinsä ja että koulutuksen sisällöissä voidaan ennakoida työelämän tulevia osaamistarpeita, joille osaltaan luovat pohjaa korkeakoulujen ja työelämän väliset tutkimus- ja kehittämishankkeet. -- Korkeakoulujen tarjoaman opetuksen ajantasaisuus turvataan niin, että se parhaalla mahdollisella tavalla palvelee työelämän muuttuvia osaamistarpeita. Tämä edellyttää tiivistä vuorovaikutusta työelämän, yritysten ja alueiden kanssa.... Opintojen ohjauksessa ja opiskelijoiden henkilökohtaisissa opintosuunnitelmissa korostuu opiskelijan työuran hahmottuminen opintojen aikana. Tätä tuetaan harjoittelua kehittämällä sekä opinnäytetöiden kytkemisellä työelämän tarpeita palveleviin tutkimusja kehittämishankkeisiin." (Koulutus ja tutkimus 2007-2012, 38.)

Kiinnostuksesta korkeakoulutuksen tuottamiin oppimistuloksiin kertoo myös OECD:n (2011) käynnistämä korkeakouluopiskelijoiden osaamisen kansainväliseen mittaamiseen tähtäävä esitutkimus AHELO (Assessment of Higher Education Learning Outcomes). Tarkoituksena on selvittää, onko korkeakouluopetuksen tuottaman osaamisen arviointi kansainvälisesti ja kulttuurienvälisesti mahdollista. Hankkeessa tarkastellaan oppimistuloksia kahdella tieteenalalla, taloustieteessä ja tekniikassa. Lisäksi tutkimuksessa on yleisiä taitoja tarkasteleva osa (generic skills strand), jossa kohteena on kriittinen ajattelu, analyyttinen päättely, ongelmanratkaisutaidot ja kirjalliset kommunikaatiotaidot. Myös Suomi osallistuu yleisten taitojen arvioinnin osuuteen (Ursin \& Hyytinen 2010; ks. http://ktl.jyu.fi/ktl/ahelo).

Tämän artikkelin tarkoituksena on analysoida yleisten työelämätaitojen problematiikkaa suomalaisissa korkeakouluissa ja hahmottaa erilaisia malleja, joiden avulla korkeakoulut ovat mukana työelämätaitojen kehittämisessä. Seuraavassa tarkastelemme ensin työelämätaitoja koskevaa tutkimuskirjallisuutta, jonka jälkeen esittelemme tutkimuksemme keskeisiä tuloksia. 


\section{TYÖELÄMÄTAIDOT KÄSITTEENÄ JA TUTKIMUKSEN KOHTEENA}

Kansainvälisessä kirjallisuudessa koulutuksen tuottamista yleisistä työelämätaidoista käytetään monia eri käsitteitä, kuten transferable skills, generic skills, generic attributes, generic competences, generic capabilities tai key skills (Jones 20092009; Kember ym. 2007; Barrie 2007). Termit on usein suomennettu geneeriksi taidoiksi tai yleisiksi työelämätaidoiksi. Niillä tarkoitetaan sellaista osaamista, jota koulutuksen tulisi tuottaa alasta riippumatta ja jota voi hyödyntää erilaisissa tehtävissä. Esimerkiksi erilaiset kriittisen ja tieteellisen ajattelun taidot, erilaiset sosiaaliset taidot, kommunikaatiotaidot, ongelmanratkaisutaidot tai projektityötaidot mainitaan usein esimerkkeinä tällaisesta osaamisesta. Yksi käytetyistä termeistä, transferable skills, viittaa myös oletukseen siitä, että nämä taidot olisivat siirrettävissä alalta toiselle tai kontekstista toiseen. Viime aikoina tätä käsitystä on kuitenkin kritisoitu ja on korostettu, että myös geneeriset taidot ovat paljolti konteksti- ja alasidonnaisia (ks. Bereiter \& Scardamalia 2003, 55). Esimerkiksi kommunikaatiotaidot mainitaan usein tällaisena "siirrettävänä" yleistaitona, mutta vaikkapa lääkärin, insinöörin, ydinfyysikon tai uutistoimittajan tarvitsemilla kommunikaatiotaidoilla on varsin erilaiset käyttöympäristöt.

Monissa julkaisuissa on pyritty erittelemään ja määrittelemään, minkälaisia tietoja ja taitoja yleistaidot sisältävät (Gilbert ym. 2004; Kallioinen 2010). Toisaalta on myös esitetty kriittisiä näkemyksiä geneeristen taitojen käsitteestä ja sen hyödyllisyydestä koulutuksessa (Barnett 2004; Bereiter \& Scardamalia 2003). Näissä kannanotoissa painotetaan sitä, ettei nopeasti muuttuvassa maailmassa voida täsmällisesti tietää, minkälaista osaamista tulevaisuudessa tarvitaan. Tämän vuoksi korostetaan, että yksittäisten taitojen sijasta olisikin syytä kiinnittää huomiota elinikäisen oppimisen edellytysten luomiseen, huolehtivan, sinnikkään, kriittisen ja eettisen ihmisluonteen tukemiseen sekä sellaisten oppimisympäristöjen luomiseen, joissa yhteisöllisesti luodaan uutta.

Myös pedagogisessa kehittämistyössä on nostettu entistä enemmän tavoitteeksi työelämätaitojen kehittäminen. On kehitetty erilaisia pedagogisia ratkaisuja, joiden avulla toivotaan perinteistä opetusta pa- remmin vastattavan työelämätaitojen kehittämisen haasteeseen (Ballantine \& McCourt Larres 2007; Tynjälä ym. 2009; Lonka \& Paganus 2004; Sarja 2004). Myös sellaisissa pedagogisissa malleissa, joissa pyritään asiantuntijuuden tai ammattiosaamisen kokonaisvaltaiseen kehittämiseen, työelämätaitojen kehittämisen problematiikka on läsnä (Heikkinen ym. 2011; Tynjälä 2008, 2010; Guile \& Griffiths 2001). Kember, Leung ja Ma (2007) ovat tutkimuksessaan päätyneet siihen, että työelämätaitoja kehittävälle oppimisympäristölle ovat ominaisia seuraavat piirteet: keskeisten käsitteiden ymmärtämiseen pyrkivä, vuorovaikutuksellinen ja aktivoiva opetus, yhteisöllinen oppiminen, palaute ja tuki sekä monipuoliset oppimisen arvioinnin menetelmät. Virtasen ja Tynjälän (2011) sekä Tynjälän ym. (2011) tulokset ovat hyvin samansuuntaisia, mutta helisäävät vielä listaan teorian ja käytännön yhteyden, työelämäyhteydet, autenttisten ongelmien käsittelyn sekä pitkäjänteisen pedagogisen kehittämisen merkityksen. Integratiivisen pedagogiikan malli, jossa opetuksessa kytketään toisiinsa asiantuntijuuden keskeisiä elementtejä - teoreettista tietoa, käytännöllistä tietoa, sosiokulttuurista tietoa ja itsesäätelytietoa - näyttää olevan tutkimusten mukaan varsin lupaava pedagoginen ratkaisu (Tynjälä 2010; Heikkinen ym. 2011; Tynjälä ym. 201 1; Virtanen ym. 2011).

Alun perin tutkimuksellinen kiinnostus koulutuksen työelämäyhteyksiin ja työelämätaitoihin on lähtenyt liikkeelle ammatillisen koulutuksen tutkimuksesta. Brittitutkijat Guile ja Griffiths (2001) tutkivat vuosituhannen vaihteessa erilaisia eurooppalaisia malleja siitä, miten työharjoittelu on organisoitu ammatillisessa koulutuksessa. Tutkimuksessa identifioitiin viisi erilaista mallia: 1) perinteinen malli, jossa opiskelijat vain lähetetään työelämään, 2) kokemuksellinen malli, jossa kehitetään opiskelijan tietoisuutta osaamisestaan, 3 ) avaintaitomalli, jossa korostuvat yleisten taitojen hankkiminen ja niiden arviointi, 4) työprosessimalli, joka painottaa kokonaisvaltaisen systeemiajattelun kehittämistä ja 5) konnektiivinen malli, joka pyrkii kouluoppimisen ja työharjoittelun pedagogiseen kytkemiseen siten, että koulutus ja työelämä yhdessä luovat oppimisympäristöjä.

Emme tarkastele tässä yhteydessä näitä malleja 
yksityiskohtaisesti, mutta ne eroavat toisistaan esimerkiksi sen mukaan, millaiseksi nähdään työharjoittelun tarkoitus. Esimerkiksi perinteisessä mallissa työharjoittelulla pyritään lähinnä antamaan ensimmäinen kosketus työelämään, kun taas konnektiivisessa mallissa nähdään tavoitteena kehittää reflektiivisiä ammattilaisia edellytyksiä. (Suomeksi malleja ovat kuvanneet tarkemmin esimerkiksi Virolainen 2004 ja Tynjälä 2010).

\section{TUTKIMUSTEHTÄVÄ, -AINEISTO JA -MENETELMÄT}

Tässä esiteltävän tutkimuksen tarkoituksena on analysoida ja kuvata malleja, joilla suomalaisessa korkeakoulutuksessa on pyritty kehittämään työelämätaitoja. Tutkimus on osa laajempaa Euroopan sosiaalirahaston rahoittamaa tutkimus- ja kehittämishanketta Ohjauksen ja työelämätaitojen kehittäminen korkeaasteella (http://www.peda.net/veraja/tuvako/tuopro/tl2/ohty3). Tässä artikkelissa vastaamme seuraaviin tutkimuskysymyksiin:

\section{1) Mitkä taidot korkeakouluissa katsotaan työelä- mätaidoiksi?}

2) Minkälaisia työelämätaitojen kehittämiseen liittyviä malleja voidaan identifioida korkea-asteen koulutuksessa?

Keräsimme tutkimusaineiston fokusryhmähaastatteluin kolmesta korkeakoulusta, joista kaksi oli tiedeyliopistoja ja yksi ammattikorkeakoulu. Vaikka yliopistoilla ja ammattikorkeakouluilla on erilaiset painotukset yhteiskunta- ja työelämäsuhteissa, molempien tehtäviin sisältyy yhteiskunnallinen vuorovaikutus. Tämän vuoksi kohdistimme tutkimuksen molempiin korkeakoulusektoreihin. Myös eri tieteenaloilla ja ammattialoilla on eroja siinä, millaista työelämäsuhdetta tavoitellaan. Niinpä valitsimme haastateltavat ryhmät siten, että edustetuiksi tulivat sekä sellaiset koulutusalat, joilta valmistutaan tiettyihin ammatteihin että sellaiset alat, joilla tutkinnot ovat yleisempiä kandidaatin- ja maisterintutkintoja ilman erityistä ammattinimikettä tai -kelpoisuutta.

Anonymiteetin varmistamiseksi emme tässä yhteydessä tuo esiin tutkittuja korkeakouluja tai aloja. Haastateltavat edustivat eri ammattiryhmiä: johto- henkilöstöä, professoreja, lehtoreita, muita opettajia, opinto-ohjaajia ja työelämäpalvelujen tai vastaavia. Jokaisessa korkeakoulussa teimme kaksi haastattelua. Haastateltavia oli yhteensä 29 henkilöä. Valitsimme haastateltavat niin sanottua lumipallotekniikkaa käyttäen siten, että tutkijat selvittivät ensin, ketkä olisivat kussakin korkeakoulussa tai koulutusohjelmassa asiaa tuntevia avainhenkilöitä, minkä jälkeen pyysimme näitä henkilöitä nimeään muita asiantuntijoita.

Käsittelimme haastattelussa seuraavia teemoja: korkeakoulutuksen ja työelämän suhteet opetussuunnitelmatyössä, pedagogisissa prosesseissa ja ohjauksessa, tavoitellut työelämätaidot, työelämätaitojen kehittämisen tavoitteet ja pedagogiset erityispiirteet, teoreettisen tiedon, käytännöllisen tiedon ja itsesäätelytiedon suhteet opetuksessa, opetustoiminnan johtaminen sekä koulutuksen ja työelämän välinen verkostoituminen.

Analysoimme aineiston temaattisen laadullisen analyysin vaiheiden mukaisesti (ks. Braun \& Clarke 2006). Aluksi litteroimme digitaaliseen muotoon tallennetut haastattelut sanatarkasti. Artikkelin ensimmäinen kirjoittaja teki alustavan koodauksen, jossa luokittelimme osan aineistosta aineistolähtöisesti melko yksityiskohtaisiin kategorioihin. Tämän jälkeen tarkensimme yhdessä koodausta ja aloimme muodostaa kategorioista laajempia yläkategorioita ja teemoja. Ensimmäinen kirjoittaja jatkoi kategorisointia laajentaen sen koko aineistoon, samalla jatkuvasti tarkentaen kategorioita ja niiden välisiä suhteita. Yhteisen keskustelun pohjalta muodostimme lopulliset ylä- ja alakategoriat sekä laajemmat teemat. Kategorisoinnin edetessä nostimme abstraktiotasoa siten, että kun alustavat kategoriat nimesimme suoraan aineistosta peräisin olevin ilmauksin, muodostimme yläkategoriat ja laajemmat teemat käsitteellisimmiksi ja yleisemmän tason luokitteluiksi. Esimerkiksi työelämämallien analysoinnissa kolmessa pääkategoriassa alkoi korostua kolme käsitettä, jotka lopullisessa mallinnuksessa esiintyvät mallien nimissä. Kategorioiden ja teemojen välisten keskinäisten suhteiden tarkastelu nosti esiin tiettyjä dimensioita, joista alkoivat hahmottua erot lähestymistavoissa korkeakoulujen työelämäsuhteiden hoitamiseen. Viimeisessä vaiheessa kävimme aineiston uudelleen läpi, jolloin 
dimensiot, pääteemat ja kategoriat saivat lopulliset nimikkeensä ja muotonsa. Analyysi oli aineistolähtöistä siinä mielessä, että teimme koodauksen ja luokittelun induktiivisesti aineistosta käsin, mutta luonnollisesti tutkijoiden teoreettinen viitekehys ja käsitteelliset apparaatit ovat vaikuttaneet tulkinnassa. Analyysiprosessia voitaneenkin parhaiten kuvata abduktiivisen päättelyn prosessiksi, jossa tulos syntyy aineiston ja teorian vuorovaikutuksessa.

\section{TULOKSET}

\section{Haastateltavien näkemykset työelämätaidoista}

Työelämätaidot voidaan luokitella tässä kuvaamassamme tutkimuksessa viiteen kategoriaan: 1) akateemiseen tiedonmuodostukseen ja tieteelliseen ajatteluun liittyvät taidot, 2) tiedon integraation taidot, 3) sosiaaliset ja viestintätaidot, 4) itsesäätelytaidot sekä 5) johtamis- ja verkostotaidot.

Akateemiseen tiedonmuodostukseen ja tieteelliseen ajatteluun liittyvien taitojen osalta korkeakouluissa työskentelevät haastateltavamme eivät tee erottelua "akateemisiin taitoihin" ja "työelämätaitoihin”, vaan akateemiset taidot nähdään osana korkeasti koulutettujen työelämäosaamista. Tieteellisen ajattelun ja tiedonmuodostuksen taitojen kehittämisessä nousevat esiin tieteen- tai koulutusalan perusteorioiden, käsitteiden ja tiedontuottamisen tradition omaksuminen. Osana opiskelijoiden kriittisen ajattelun kehittämistä korostetaan osallistumista alan eettisten, moraalisten ja valtakysymysten pohtimiseen.

Tiedon integraation taidot tarkoittavat teoreettisen ja käytännöllisen tiedon yhdistämisen taitoa. Tiedon integraation katsotaan edellyttävän työelämässä tapahtuvaa oppimista, jonka ytimenä on ongelmanratkaisutaitojen kehittäminen, kokemuksista oppiminen ja teoreettisen tiedon nivominen käytännön kysymysten ratkaisemiseen. Opiskelijoiden katsotaan oppivan erityisesti ryhmässä ja tiimeissä sekä opettajien ja työelämän edustajien kanssa tehtävässä yhteistyössä ja oppivan teoreettisen opiskelun avulla käsitteiden hallintaa ja soveltamista sekä yhteisöllistä tiedonmuodostusta. Tällaisen oppimisen nähdään tukevan monialaisen ja monitieteisen tiedon rakentamista sekä innovaatiotoimintaa. Tämä tulee esiin sekä yliopisto- että ammattikorkeakoulukontekstissa.

Sosiaaliset ja viestintätaidot ovat laaja työelämätaitojen kokonaisuus, jonka voi tiivistää erityisesti yhteistyössä toimimisen taitoihin sekä ryhmäprosessien ja ryhmädynamiikan ymmärtämiseen. Yhteistyön pelisäännöt, toimintatavat sekä tiedon ja osaamisen jakaminen korostuvat. Yhteisen työn tekemisen taidoiksi nähdään myös tilannetajuisuus, rohkeus ja innovatiivisuus. Näitä tarvitaan, jotta ryhmän oivalluspotentiaali lisääntyisi ja edistäisi tiedon muodostamista sekä ongelmanratkaisua. Haastateltavien mukaan erityisesti toiminnallinen opetus kehittää opiskelijoiden viestintä- ja esiintymistaitoja. Opiskelijat oppivat tällöin myös organisointi-, koordinointi-, neuvottelu- ja kokoustaitoa, eri näkökulmien arvostamista, kuuntelua, ideointia, keskustelua ja perspektiivin vaihtoa.

Itsesäätelytaitojen käsitetään olevan suhteen luomista omaan oppimiseen reflektiivisessä prosessissa, jota opetushenkilöstö tukee ja ohjaa. Haastatellut luonnehtivat itsesäätelytaitoja osaksi elinikäisen oppimisen taitoja. Itsesäätely on joustavuutta ja tilanteen mukaista toimintaa kompleksissa tilanteissa ja erilaisissa konteksteissa. Niissä haastatellut katsovat opiskelijoiden oppivan keskeneräisyyden, monitulkintaisuuden ja epävarmuuden sietoa. Tärkeänä itsesäätelytaitona nähdään myös oman osaamisen tunnistaminen. Työskentelyä henkilökohtaisen oppimissuunnitelman (HOPS) laatimiseksi pidetään tärkeänä itsesäätelytaitojen oppimisen välineenä.

Johtamis- ja verkostoitumistaidot palautuvat työyhteisön jäsenenä toimimiseen, työssä jaksamiseen, työmotivaatioon sekä persoonan sovittamiseen työhön ja yhteistyösuhteisiin. Haastatellut toivovat korkeakoulutuksen kehittävän opiskelijoista työelämän muutoksen tekijöitä sopeutumisen asemesta. Johtamistaitoina haastatteluissa korostetaan suunnittelun, ryhmän toiminnan ohjaamisen, vakuuttamisen ja vaikuttamisen sekä itsensä johtamisen taitoja. Verkostoitumisen taitoina haastatellut näkevät verkostoitumistarpeiden hahmottamisen, osallistumisen, itsensä alttiiksi laittamisen ja vastuunoton. Opintojen aikaisen verkostoitumisen työelämään katsotaan edistävän opiskelijoiden työllistymistä. 
Taulukko 1. Työelämätaitojen kehittämisen mallit

\begin{tabular}{|c|c|c|c|c|}
\hline \multicolumn{2}{|l|}{ Ulottuvuus } & \multirow{2}{*}{$\begin{array}{l}\text { Spesialistimalli } \\
\text { Koulutuksessa painotetaan tut- } \\
\text { kimusperustaisuutta ja tutkija- } \\
\text { koulutusta. Yhteys työelämään } \\
\text { koetaan tärkeäksi yleisellä } \\
\text { tasolla. }\end{array}$} & \multirow{2}{*}{$\begin{array}{l}\text { Integratiivinen malli } \\
\text { Opiskelijoille järjestetään } \\
\text { mahdollisuuksia osallistua ja } \\
\text { oppia autenttisissa oppimis- } \\
\text { ympäristöissä. }\end{array}$} & \multirow{2}{*}{$\begin{array}{l}\text { Verkostoituneen kulttuurin malli } \\
\text { Koulutuksen arvopohjassa työ- } \\
\text { elämälähtöisyys, työelämän ja } \\
\text { koulutuksen luottamus, sitoutu- } \\
\text { minen yhteistyöhön, osaaminen } \\
\text { ja oppiminen on jaettua. }\end{array}$} \\
\hline \multirow{4}{*}{$\begin{array}{l}\text { Rakenteelliset } \\
\text { tekijät }\end{array}$} & $\begin{array}{l}\text { Koulutuksen } \\
\text { ja työelämän } \\
\text { suhteet }\end{array}$ & & & \\
\hline & $\begin{array}{l}\text { Työelämä- } \\
\text { suhteiden } \\
\text { hoitaminen } \\
\text { koulutuk- } \\
\text { sessa }\end{array}$ & Keskitetty spesialisteille. & $\begin{array}{l}\text { Kuuluu kurssien ja projektien } \\
\text { opettajille yhteisöllisesti. }\end{array}$ & $\begin{array}{l}\text { Upotettu rakenteisiin, perusteh- } \\
\text { tävän määrittelyyn, opetussuun- } \\
\text { nitelmaan. }\end{array}$ \\
\hline & Johtaminen & $\begin{array}{l}\text { Hajautettua, ei-korostettua, } \\
\text { kollegiaalista, hallintohen- } \\
\text { kilöstö vastaa laitoksen joh- } \\
\text { tamisesta yhdessä asia- tai } \\
\text { ainevastuuhenkilöiden kanssa. } \\
\text { Opetussuunnitelmaa ja toimin- } \\
\text { tatapoja kehitetään laajapohjai- } \\
\text { sissa työryhmissä. }\end{array}$ & $\begin{array}{l}\text { Johtajat luovat edellytyksiä, } \\
\text { koulutuksen kokonaisuutta } \\
\text { johdetaan oppiaineittain ha- } \\
\text { jautuvana toimintamallina, } \\
\text { opetuskokeiluja ja projekteja } \\
\text { johtavat ja koordinoivat niihin } \\
\text { osallistuvat opettajat. }\end{array}$ & $\begin{array}{l}\text { Johtamisessa yhdistetään } \\
\text { perustehtävä, tutkimus-, ke- } \\
\text { hittämis- ja innovaatiotoiminta } \\
\text { sekä aluekehitystyö sekä peda- } \\
\text { goginen ja toiminnallinen johta- } \\
\text { minen. Tietoista, suunnitelmal- } \\
\text { lista, strategiaan perustuvaa, } \\
\text { laaja-alaista, ohjaavaa, johtajien } \\
\text { oppiminen muutoksen edellytys. }\end{array}$ \\
\hline & $\begin{array}{l}\text { Verkostoitu- } \\
\text { minen }\end{array}$ & $\begin{array}{l}\text { Verkostoituminen koulutusalan } \\
\text { sisällä ja korkeakouluorgani- } \\
\text { saation sisällä on löyhää. }\end{array}$ & $\begin{array}{l}\text { Verkosto perustuu henki- } \\
\text { lösuhteille. Haavoittuvuus } \\
\text { henkilövaihdoksissa. Verkosto } \\
\text { laajenee projekteittain. }\end{array}$ & $\begin{array}{l}\text { Koulutusrakenteet, opetus- } \\
\text { suunnitelma ja toimintatavat } \\
\text { suosivat verkostoitumista. } \\
\text { Verkostoitumista pidetään myös } \\
\text { työelämäkompetenssina. }\end{array}$ \\
\hline \multirow{5}{*}{$\begin{array}{l}\text { Pedagogiset } \\
\text { tekijät }\end{array}$} & $\begin{array}{l}\text { Työelämätai- } \\
\text { dot opetus- } \\
\text { suunnitel- } \\
\text { massa }\end{array}$ & $\begin{array}{l}\text { Työelämäasiat sijoitettu erilli- } \\
\text { siksi kursseikseen. }\end{array}$ & $\begin{array}{l}\text { Työelämäasioita ja -taitoja py- } \\
\text { ritään integroimaan kurssien } \\
\text { teoreettisiin sisältöihin. }\end{array}$ & $\begin{array}{l}\text { Työelämätaidot nivelletty osaksi } \\
\text { opetussuunnitelma-ajattelua ja } \\
\text { kaikkea toimintaa. }\end{array}$ \\
\hline & $\begin{array}{l}\text { Pedagoginen } \\
\text { yhteistyö }\end{array}$ & $\begin{array}{l}\text { Erityistyöntekijät opetushenki- } \\
\text { löstön rinnalla, työntekijöiden } \\
\text { selkeä työnjako. }\end{array}$ & $\begin{array}{l}\text { Työelämäkurssien yhteissuun- } \\
\text { nittelu. }\end{array}$ & $\begin{array}{l}\text { Pitkäkestoinen opettajien yh- } \\
\text { teissuunnittelu ja työskentely } \\
\text { yhdessä, osaamisen jakaminen, } \\
\text { kollegatuki- ja valmennus. }\end{array}$ \\
\hline & Oppiminen & Teorian oppimisen painotus. & $\begin{array}{l}\text { Suuntana aktiivinen yhteisöl- } \\
\text { linen oppiminen ja oppimaan } \\
\text { oppiminen sekä autenttisten } \\
\text { oppimisympäristöjen hyödyn- } \\
\text { täminen. }\end{array}$ & $\begin{array}{l}\text { Eri toimijoiden oppiminen on } \\
\text { toisiaan ruokkivaa, yhteistoimin- } \\
\text { tainen opiskelijoiden, opettajien } \\
\text { ja työelämän hankeyhteistyö } \\
\text { muuttaa ajattelua ja toiminta- } \\
\text { tapoja. }\end{array}$ \\
\hline & $\begin{array}{l}\text { Asiantun- } \\
\text { tijuuden } \\
\text { elementit } \\
\text { opetuksessa }\end{array}$ & $\begin{array}{l}\text { Teoreettinen tieto, käytännöl- } \\
\text { linen tieto ja itsesäätelytiedot } \\
\text { nähdään erillisinä. }\end{array}$ & $\begin{array}{l}\text { Teoreettinen, käytännöllinen } \\
\text { ja itsesäätelytieto integroituvat } \\
\text { työelämäkursseilla. Muilla } \\
\text { kursseilla saattaavat jäädä } \\
\text { erillisiksi. }\end{array}$ & $\begin{array}{l}\text { Teoreettinen, käytännöllinen ja } \\
\text { itsesäätelytieto fuusioituneet. } \\
\text { Teorian tarve lähtee kulloisesta- } \\
\text { kin ratkaistavasta ongelmasta. } \\
\text { Hankeoppiminen. }\end{array}$ \\
\hline & Ohjaus & $\begin{array}{l}\text { Erikoistunut ohjaaja työskente- } \\
\text { lee koulutuksen ja työelämän } \\
\text { siirtymässä. Ohjaa myös opin- } \\
\text { tojen aikana. Erillinen työelä- } \\
\text { mään ohjaus. HOPS-ohjaus. }\end{array}$ & $\begin{array}{l}\text { Opettajat ja työelämän } \\
\text { edustajat sisällöllisinä ja } \\
\text { metodisina ohjaajina työelä- } \\
\text { mäkursseilla. Pääaineen ja } \\
\text { graduaihevalintojen yhteydes- } \\
\text { sä ohjausta. HOPS-ohjaus. }\end{array}$ & $\begin{array}{l}\text { Kaikki opettajat työskentelevät } \\
\text { oppimisen ohjaajana hankeop- } \\
\text { pimisessa. Ohjauksen, arvioin- } \\
\text { nin ja reflektoinnin katsotaan } \\
\text { olevan läheisiä ja rinnakkaisia } \\
\text { prosesseja. }\end{array}$ \\
\hline \multirow{3}{*}{$\begin{array}{l}\text { Opetuksen, } \\
\text { oppimisen, } \\
\text { ohjauksen ja } \\
\text { opiskelija- } \\
\text { hyvinvoinnin } \\
\text { suhteet }\end{array}$} & $\begin{array}{l}\text { Elementtien } \\
\text { suhteet }\end{array}$ & $\begin{array}{l}\text { Selkeät, erilliset oppijan, opet- } \\
\text { tajan ja ohjaajan roolit. Opetus, } \\
\text { oppiminen, ohjaus ja opiskelija- } \\
\text { hyvinvointi erillisiä. }\end{array}$ & $\begin{array}{l}\text { Opettajien ja opiskelijoiden } \\
\text { yhteistyö syvenee. Opiskelijoi- } \\
\text { den oppimisprosessien ohjaa- } \\
\text { minen ja vuorovaikutus } \\
\text { Oppiminen, opetus ja ohjaus } \\
\text { integroituvat. }\end{array}$ & $\begin{array}{l}\text { Opiskelija on toiminnan keski- } \\
\text { össä. Opetus, oppiminen, ohjaus } \\
\text { ja opiskelijoiden hyvinvoinnista } \\
\text { huolehtiminen fuusioituvat. }\end{array}$ \\
\hline & $\begin{array}{l}\text { Oppimisen, } \\
\text { opetuksen, } \\
\text { ohjauksen ja } \\
\text { hyvinvoinnin } \\
\text { korostus }\end{array}$ & Opetus & $\begin{array}{l}\text { Oppiminen, ohjaus ja hyvin- } \\
\text { vointi }\end{array}$ & Kaikki \\
\hline & $\begin{array}{l}\text { Työelämä- } \\
\text { taitojen ko- } \\
\text { rostus }\end{array}$ & $\begin{array}{l}\text { Akateemiseen tiedonmuodos- } \\
\text { tukseen ja tieteelliseen ajatte- } \\
\text { lun taidot }\end{array}$ & $\begin{array}{l}\text { Itsesäätelytaitojen kehittämien } \\
\text { Sosiaaliset taidot }\end{array}$ & $\begin{array}{l}\text { Tiedon integraation taidot } \\
\text { Johtaminen ja verkostoituminen }\end{array}$ \\
\hline
\end{tabular}




\section{Työelämätaitojen kehittämisen mallit}

Tässä tarkastelussa esitettävät mallinnukset eivät ole valmiita korkeakoulujen esittämiä malleja vaan tutkimuksen tuloksena syntyneitä analyyttisia rakennelmia. Haastattelujen perusteella työelämätaitojen kehittämisessä erottuu kolme mallia, jotka nimesimme spesialistimalliksi, integratiiviseksi malliksi sekä verkostoituneen kulttuurin malliksi. Mallinnusten avulla voidaan tarkastella korkeakoulujen, niiden yksiköiden, tiettyjen koulutusohjelmien tai kurssien lähestymistapoja työelämätaitojen kehittämiseen. Malleja erottavia dimensioita ovat 1) koulutuksen ja työelämän välisen yhteistyön rakenteet, 2) pedagogiikka sekä 3) opetuksen, oppimisen, ohjauksen ja opiskelijoiden hyvinvoinnin edistämisen väliset suhteet.

Spesialistimallissa on erityisenä piirteenä työelämäyhteyksien ja työelämätaitojen kehittämisen delegointi erityisasiantuntijoille ja työelämätaitojen opettaminen erillisillä kursseilla. Integratiivista mallia voi luonnehtia osa-aikaisen yhteisöllisen pedagogiikan malliksi. Tämä tarkoittaa, että perinteisen korkeakouluopetuksen ohella järjestetään vuorovaikutteisia, teoriaa ja käytäntöä integroivia kursseja. Opetuksen teoreettinen viitekehys, metodit ja toteutus suunnitellaan opettajien yhteistyössä. Opittua reflektoidaan sekä opiskelijoiden kesken että opettajien johdolla. Verkostoituneen kulttuurin mallissa korkeakoulun opetussuunnitelmatyön, koulutuksen järjestämisen, johtamisen ja toiminnan ytimenä ovat opiskelija- ja työelämälähtöisyys sekä koulutusinstituutin eri toimintojen fuusioiminen. Oppiminen käsitetään laajasti, ei vain opiskelijoiden, vaan myös opettajien, johtajien, organisaatioiden, alueiden ja työelämän oppimiseksi. Esitämme mallit ulottuvuuksineen tiivistetysti taulukossa 1 .

Seuraavassa tarkastelemme malleja erottavien päädimensioiden keskeisiä sisältöjä malleittain.

Työelämätaitojen kehittämisen rakenteellisina tekijöinä erottuvat aineistossamme 1) koulutuksen ja työelämän suhteet, 2) työelämäsuhteiden hoitaminen koulutuksessa sekä 3) johtamisen ja 4) verkostoitumisen näkökulmat.

Spesialistimallissa työelämäsuhteiden hoitaminen delegoituu erityisille työntekijöille. Usein nämä ovat esimerkiksi korkeakoulujen rekrytointipalveluissa työskenteleviä henkilöitä tai erityisistä työelämäkursseista tai harjoittelujaksoista vastaavia opettajia. Työelämätaitojen kehittämiseen tähtäävää harjoittelua on sisällytetty tutkintoihin, työelämän edustajat vierailevat korkeakouluissa ja opiskelijat työpaikoilla. Koulutusyksiköillä on alumnisuhteita ja esimerkiksi opetussuunnitelmayhteistyöhön osallistuu työelämän edustajia. Hallintohenkilöstö vastaa laitosten johtamisesta. Työnjakoon perustuen asia- tai ainevastuuhenkilöillä voi olla johtamis- ja hallintovastuita. Verkostoituminen työelämään on spesialistimallissa henkilösuhteisiin ja viranhaltijoiden tehtäviin kytkeytyvää ja edustuksellista.

Integratiivisessa mallissa koulutuksen ja työelämän yhteistyössä korostetaan opiskelijoiden osallistumisen mahdollisuuksia ja oppimista autenttisissa oppimisympäristöissä. Autenttisia oppimisympäristöjä hyödynnetään myös spesialistimallissa (yleensä harjoittelussa), mutta integratiivinen mallia eroaa spesialistimallista siinä, että kun spesialistimallissa työelämäkurssit ovat muusta opetuksesta ja teoreettisesta tiedosta täysin erillisiä, integratiivisessa mallissa pyritään yhdistämään eli integroimaan teoriaa ja käytäntöä. Tämä voi tapahtua joko autenttisissa työympäristöissä tai korkeakoulun sisällä erilaisten simulaatioiden ja harjoitusten avulla. Keskeistä on, että teoreettista tietoa sovelletaan käytäntöön ja käytännön kokemuksia reflektoidaan teoreettisen tiedon valossa. Usein näillä kursseilla korostetaan yhteisöllistä oppimista.

Samoin kuin spesialistimallissa, myös integratiivisessa mallissa työelämäsuhteiden hoitaminen on usein keskittynyt tietyille henkilöille, eli teoriaa ja käytäntöä integroivien kurssien opettajille, jotka ovat yleensä muodostaneet kattavat työelämäverkostot. Johto tukee innovatiivista, työelämäläheistä opetusta, pyrkii raivaamaan toiminnalta hallinnollisia esteitä ja allokoi resursseja opetukseen.

Verkostoituneen kulttuurin mallissa opiskelija- ja työelämälähtöisyys on määritelty koulutuksen arvolähtökohdiksi. Työelämätaitojen kehittäminen on fuusioituneena kaikkialle toimintaan. Opetus järjestetään pääasiassa monialaisissa hankkeissa työelämässä. Opetuksessa korostetaan osaamisen kehittämistä ja toiminnan, oppimisen ja johtamisen jakamista. Työ- 
elämäsuhteet ovat osa opetussuunnitelmaa ja toimintastrategiaa. Koulutuksen ja työelämäsuhteiden sekä opiskelijoiden työelämätaitojen kehittyminen ovat osa koulutusinstituution arviointia.

Mallissa johtaminen on hyvin tietoista, suunnitelmallista, strategiaan perustuvaa, ohjaavaa ja asiantuntijoiden substanssiosaamiseen luottavaa. Johtajien toiminnassa korostuvat arvioinnin ja kehittämistyön yhdistäminen. Koulutusinstituutiossa verkostoitumista pidetään tärkeänä kulttuurisena tekijänä. Koulutusrakenteet, opetussuunnitelma ja toimintatavat suosivat verkostoitumista. Se hahmotetaan myös opiskelijoiden työelämäkompetenssina.

Työelämätaitojen kehittämisen pedagogiset tekijät ovat 1) työelämätaitojen painotus opetussuunnitelmassa, 2) pedagoginen yhteistyö työelämätaitojen opetuksessa, 3) oppiminen, 4) teoreettisen, käytännöllisen ja itsesäätelytiedon painotukset koulutuksessa sekä 5) ohjaus.

Spesialistimallissa työelämäasiat on sijoitettu erillisiksi kursseiksi opetussuunnitelmassa. Opetussuunnitelmatyö on yhteisöllistä, mutta opetusta hoidetaan pitkälle viedyn työnjaon mukaan ja työelämäasiat on delegoitu spesialisteille. Koulutuksessa korostetaan teorian opetusta ja oppimista. Tutkimustyötä korostetaan myös osana opetusta. Teoreettinen, käytännöllinen ja itsesäätelytieto nähdään erillisinä. Työelämänäkökulma näyttäytyy löyhästi opetussuunnitelmassa painotuksen ollessa opiskelujen loppuvaiheessa.

Työelämätaitojen kehittäminen on delegoitu spesialisteille, työelämäkysymyksiin erikoistuneille työntekijöille, kuten opintoasioista vastaavalle ja rekrytointipalveluiden henkilökunnalle. He ohjaavat opiskelijoita myös henkilökohtaisissa kysymyksissä opintojen aikana. Erityisesti yliopistokoulutuksessa nousee tarve tehdä opintoihin implisiittisesti sisältyvät työelämätaidot näkyväksi. Oppimisprosesseihin sisältyvät työelämätaidot eivät hahmotu opiskelijoille ilman koulutuksessa ja työelämässä tapahtuvan oppimisen reflektointia.

Integratiivisessa mallissa pedagogisena lähtökohtana on suuntautuminen työelämään. Opetussuunnitelman lähtökohta on, että opetus rakennetaan ainakin osittain yhteistyössä työelämän kanssa ja se poh- jautuu kokeilemiseen ja oppimiseen työelämässä tai työelämää simuloivissa tilanteissa ja harjoituksissa. Malli perustuu vuorovaikutteisuuteen, käytännön tilanteiden käsitteellistämiseen ja opitun reflektointiin.

Opettajien yhteissuunnittelu on tiivistä. Opintokokonaisuuksien välisiä yhteyksiä syntyy silloin, kun opettajilla on tietoa toistensa toiminnasta ja opintojaksoista. Kurssit järjestetään yhteistoiminnallisiksi ja niissä korostuvat teoreettisen, käytännöllisen ja itsesäätelytaitojen oppiminen sekä niiden integrointi toisiinsa. Opintojaksojen välille pyritään luomaan koheesiota niin, että toiminnallisia työelämälähtöisiä opintoja syvennetään teoriaopetuksen kursseilla tai teoriakursseja kytketään esimerkiksi työharjoitteluun.

Opettajat ja työelämän edustajat työskentelevät työelämälähtöisten opintojen sisällöllisinä ja metodisina ohjaajina. Toiminnalliset menetelmät vaativat opettajaresursseja, sillä opetusryhmät eivät voi olla kovin suuria. Pienryhmäopetuksessa keskustelu, reflektointi ja argumentointi ovat keskeisiä. Integratiivinen malli lähentää korkeakoulutusta muuhun yhteiskuntaan.

Verkostoituneen kulttuurin mallissa opetussuunnitelmaprosessi on jatkuva. Opetussuunnitelmatyössä on otettu huomioon korkeakoulualojen tiedontuottamisen rajapinnat ja tiedon soveltaminen käytäntöön. Opetuksessa pidetään tärkeänä opiskelijan osaamisen kehittämistä ja työelämälähtöisyyttä. Osaamista jaetaan monialaisesti henkilöstön, opiskelijoiden ja työelämän edustajien kesken korkeakoulun ja työelämän verkostoissa.

Teoriaa voidaan oppia monista lähteistä. Esimerkiksi työelämän ajantasainen tieto saavuttaa opiskelijat hankeoppimisessa. Opettajat ovat verkostoituneet laajasti alansa asiantuntijoiden kanssa. Kaikki opettajat työskentelevät oppimisen ohjaajina opiskelijoiden oppimisprosesseissa. Ohjauksen, arvioinnin ja reflektoinnin katsotaan olevan läheisiä ja rinnakkaisia prosesseja.

\section{Opetuksen, oppimisen, ohjauksen ja opis-} kelijoiden hyvinvoinnin edistämisen väliset suhteet nousivat kolmea mallia erottelevaksi tekijäksi. Näiden keskeisten koulutusinstituutioiden toimintojen suhde toisiinsa näyttäytyi joko elementtien keskinäisenä yhteytenä tai yhteyden puuttumisena koulutusinstituution toiminnassa. 
Spesialistimallissa opetuksen, ohjauksen ja oppimisen suhdetta voidaan kuvata erillisinä. Opetus ja ohjaus ovat delegoitu eri työntekijöille. Opettajien, ohjaajien ja opiskelijoiden roolit erottuvat selkeästi. Koulutuksessa korostetaan opiskelijoiden autonomisuutta niin, että opiskelijoiden ohjaustarpeet saattavat jäädä katveeseen jopa kaikilta työntekijöiltä. Opetussuunnitelman mukaan oppiminen rakentuu toisistaan erillisistä tai korkeintaan löyhäyhteyksisistä moduuleista, joiden yhteyksien tulkinnoissa opiskelijat saattavat jäädä yksin.

Integrativinen mallissa pedagogiset prosessit korostavat yhteistoimintaa. Teoriaa, käytäntöä ja itsesäätelytaitoja toisiinsa kytkevä integratiivinen opetus on periodimaista eli toteutuu joillakin tietyillä kursseilla. Tällaisten periodien aikaan opettajien ja opiskelijoiden yhteistyö on tiivistä. Opetus, oppiminen ja ohjaus lähestyvät toisiaan. Opettajien välinen yhteistyö koetaan merkityksellisenä myös opettajien oman oppimisen ja reflektion kehittämisessä. Innovatiivisten, yhteistoiminnallisten pedagogisten ratkaisujen katsotaan ohjaavan opiskelijoiden ajattelun kehittymistä.

Verkostoituneen kulttuurin mallissa opetuksen, ohjauksen ja oppimisen suhde on fuusioitunut. Tämä tarkoittaa kokonaisvaltaista opiskelijan kohtaamista sekä opettajien ja opiskelijoiden suhteen ja roolien muutosta. Opetus ja ohjaus korostavat opiskelijalähtöisyyttä. Opettajat ovat valmentajia ja sparraajia. Kaikki työntekijät sitoutuvat opiskelijoiden ohjaamiseen. Opiskelijat mentoreina osallistuvat nuorempien opiskelijoiden ohjaamiseen. Mallissa pidetään tärkeänä myös työelämän edustajien antamaa ohjausta opiskelijoille. Opiskelijoiden, opettajien, johtajien ja työelämän edustajien oppiminen laajenee koulutusorganisaatioiden ja työelämän oppimisesta alueen oppimiseen. Yhteisöllisyyden katsotaan edistävän myös opiskelijoiden sekä kaikkien toimintaan osallistuvien hyvinvointia.

\section{JOHTOPÄÄTÖKSET}

Haastateltavamme kuvasivat työelämätaitoja samansuuntaisesti kuin niitä on ryhmitelty kansainvälisissä koulutuspoliittisissa ja tieteellisissä dokumenteissa. Ryhmittelimme ne 1) akateemiseen tiedonmuodostukseen ja tieteelliseen ajatteluun liittyviksi taidoiksi,
2) tiedon integroinnin taidoiksi, 3) sosiaalisiksi ja viestintätaidoiksi, 4) itsesäätelytaidoiksi sekä 5) johtamis- ja verkostotaidoiksi. Esimerkiksi UNESCO:n (1998) maailmanlaajuisen korkeakoulutuksen konferenssin päätöslauselmassa (WCHE) sekä Knapperin ja Cropleyn (2001) elinikäistä oppimista koskevissa työelämätaitojen kuvauksissa korostuvat oman tieteenalan akateemisen tiedon lisäksi osallistuminen monitieteiseen ongelmanratkaisuun, innovatiivisuus ja yrittäjyys. Tässä kuvatussa tutkimuksessa nimitämme näitä taitoja yhteisesti tiedon integraation taidoiksi, koska ne edellyttävät eri konkteksteista saatavan ja erilaisten tiedon muotojen yhdistämistä. Globalisaatio ja maailmanlaajuiset talouden, ympäristön ja yhteiskuntien haasteet nostavat korkeakouluista valmistuneiden taidoiksi myös epävarmuuden sietämisen, erilaisten kulttuurien ymmärtämisen, yhteistyön, vuorovaikutuksen ja vastuunottamisen taidot (Kreber 2006; Knapper \& Cropley 2001). Nämä nousivat vahvasti esiin myös tutkimuksessamme. Samat taidot toistuvat myös eurooppalaisessa sekä kansallisessa tutkintojen viitekehyksessä, tosin huomattavasti spesifimmässä muodossa.

Kaiken kaikkiaan haastattelumme antavat viitteitä siitä, että korkeakoulut eivät ole ainoastaan omaksuneet työelämätaitoihin liittyvää koulutuspoliittista retoriikkaa, vaan myös näyttävät pyrkivän toteuttamaan koulutusta, jossa tavoitteeksi asetettuja taitoja tietoisesti kehitetään.

Tutkimustulostemme perusteella voidaan myös nähdä, että työelämätaitojen kehittämiseksi on korkeakoulutuksessa otettu erilaisia lähestymistapoja. Aineistomme pohjalta hahmottui kolme mallia, jotka nimesimme spesialistimalliksi, integratiiviseksi malliksi ja verkostoituneen kulttuurin malliksi. Spesialistimallissa työelämäsuhteet ja työelämätaitojen kehittäminen nähdään ikään kuin muusta opetuksesta erillisenä asiana, josta vastaavat asiaan erityisesti paneutuneet spesialistit. Työelämätaitojen merkitys ja tarve on havaittu. Mallia kuvastaa työelämätaitojen kehittämisessä erilaisten ja erillisten metodisten toimien runsaus. Integratiivisessa mallissa koulutuksen ja työelämän välille pyritään luomaan tiiviitä yhteyksiä ja työelämätaitojen oppimista kytketään teoreettiseen opetukseen erilaisin pedagogisin jär- 
jestelyin. Tätä mallia toteutetaan yleensä yksittäisillä kursseilla, joilla teoriatietoa, käytännöllistä osaamista ja itsesäätelytaitoja kytketään toisiinsa. Verkostoituneen kulttuurin mallissa sitä vastoin koulutuksen työelämäsuhteet ja työelämätaitojen kehittäminen nähdään koko koulutusorganisaation sisäisen ja ulkoisen verkoston toiminnaksi, jossa työelämänäkökulma on rakennettu vahvasti sisälle koulutuksen rakenteisiin, johtamisjärjestelmään ja opetussuunnitelmiin.

Guile ja Griffiths $(2001,113)$ ovat kiinnittäneet huomiota siihen, että kontekstin vaikutusta oppimiseen usein vähätellään tai sitä kuvataan mekaanisesti. Nostamalla esiin tutkimustuloksissamme koulutuksen rakenteelliset tekijät avaamme kontekstuaalisia tekijöitä, joille pedagogiset ratkaisut rakentuvat. Näin ollen rakenteelliset ja pedagogiset tekijät eivät ole irrallisia vaan kytkeytyvät toisiinsa. Tutkimuksemme osoittaa, että työelämätaitojen kehittämistä ei voi mallintaa ohi koulutusalan kontekstitekijöiden, joita ovat institutionaaliset, koulutus- tai tieteenalan historialliset ja tieteen- tai koulutusalan tiedonmuodostuksen tekijät. Eri aloilla toimitaan näiden suhteen erilaisissa ympäristöissä, jotka heijastuvat myös siihen, millä tavalla koulutuksen työelämäsuhteet hoidetaan. Toisaalta työelämätaitojen kehittämisellä sekä koulutuksen ja työelämäyhteyksillä näyttäisi olevan myös alasta riippumattomia yhteisiä tekijöitä. Näitä ovat esimerkiksi opiskelijalähtöisyyden periaate, työelämän kehitystekijöiden huomioonottaminen koulutuksen suunnittelussa ja toteuttamisessa sekä reflektiivisyyden ja itsesäätelytaitojen oppimisen merkityksen näkeminen. Kuvaamamme mallit eroavat kuitenkin teorian ja käytännön yhdistämisessä sekä siinä, millaisia käytännön työmenetelmiä koulutuksessa suositaan esimerkiksi opiskelijoiden itsesäätelytaitojen ohjaamisessa.

Verkostoituneen kulttuurin malli tarjoaa filosofisen ja tutkimusperustaisen autenttisessa oppimisympäristössä toteutetun korkeakoulupedagogisen toimintatavan. Malli sisältää kokeiluihin ja kehittämistyöhön pohjautuvia pedagogisia innovaatioita, opettamisen ja ohjauksen prosessien sisäkkäin liukumista, opettajien ja opiskelijoiden oppimisen samanaikaisuuden sekä sen, että opettajien ja opiskelijoiden itsesäätelytaidot seuraavat toisiaan; mitä enemmän opettajat tulevat tietoisiksi omasta oppimis- ja kehittämistoiminnastaan, sitä paremmin he avaavat oppimisen mahdollisuuksia opiskelijoille.

Verkostomallissa lähdetään siitä, että korkeakoulutus perustuu lähtökohdiltaan tutkimukseen ja kehittää teoreettista ymmärrystä. Teoriaopiskelun paikat voivat olla moninaiset. Teoriatarve lähtee kulloisestakin ratkaistavasta ongelmasta. Opiskelijoiden teoriatieto kehkeytyy luento-opetuksen, kirjallisuuden, tutkimisen ja havainnoinnin kautta työelämähankkeisiin kytkeytyneenä. Reflektointi ja ohjaus ovat olennainen osa oppimisprosesseja, ja tiedonhankintamenetelmien oppimista korostetaan. Arjen yhteinen työ opettaa uudenlaisia toimintatapoja. Opetus ja oppiminen ovat osallistavaa ja toiminnallista. Tällainen toimintatapa ei ole kaikille toimijoille kuitenkaan itsestään selvää, vaan opiskelijoiden oppimishistoria tai opettajien työhistoria vaikuttavat siihen, millä tavalla osallistavaan oppimiseen suhtaudutaan. Niinpä pedagoginen tuki ja johtaminen nousevat tärkeiksi. Pitkäkestoinen opettajien yhteissuunnittelu ja työskentely yhdessä kehittävät osaamisen jakamista, kollegatukea ja -valmennusta.

Analyysimme tuottamat kolme työelämätaitojen kehittämisen mallia voidaan nähdä korkeakoulutuksen erilaisina ratkaisuyrityksinä yhteiskunnan ja työelämän muutoksen aiheuttamiin paineisiin. Kun spesialistimallissa korkeakouluun on luotu perinteisten rakenteiden rinnalle erityinen työelämäasioihin erikoistunut järjestelmä, verkostoituneen kulttuurin mallissa koko koulutus ja toimintajärjestelmä on rakennettu uudelta pohjalta tiiviissä yhteistyössä työelämän kanssa. Tämä näkyy siinä, että työelämätaitojen kehittäminen muuttuu yksittäisen opiskelijan henkilökohtaisesta projektista koko korkeakoulutuksen ja työelämän väliseksi prosessiksi. Prosessia voi kuvata esimerkiksi uudenlaisena korkeakouluopettajuutena. Sitä luonnehditaan opettajien työskentelyksi koulutuksen ja työelämän rajapinnalla yhdessä toistensa ja opiskelijoiden kanssa. Opetuksen ja oppimisen prosessit lähestyvät siinä määrin, että opettajat keskustelevat oman prosessinsa merkityksestä suhteessa opiskelijoiden prosesseihin. Tilannetta kuvataan siten, että opettaja ei mene teoria edellä opetustilanteeseen, vaan tutkiminen, analysointi ja 
reflektointi tapahtuvat yhdessä opiskelijoiden kanssa. Opettajat katsovat kuitenkin, että he ovat opiskelijoiden edellä kokemuksensa, teoriataustansa ja osaamisensa vuoksi.

Hahmottamamme kolme mallia, spesialistimalli, integratiivinen malli ja verkostoituneen kulttuurin malli, näyttävät ainakin nykytilanteessa painottuvan eri tavoin kahdella korkeakoulusektorilla. Kun yliopistoissa työelämäsuhteita hoidetaan paljolti spesialistimallin ja integroituneen mallin pohjalta, ammattikorkeakoulusektorilla on noussut esiin myös verkostoituneen kulttuurin malli. Tämä ei kuitenkaan tarkoita sitä, että malli kaikkine piirteineen olisi tyypillinen ammattikorkeakoulutuksenkaan puolella. Pikemminkin voidaan sanoa, että malli on hyvin harvinainen.

Kolme työelämäsuhteiden mallia kuvannevat tietyllä tavalla myös historiallista kehitystä. Monimutkaistuvat globaalit ongelmat haastavat koko korkeakoululaitosta. Koulutusrakenteet ja pedagogiikka, jotka spesialistimallissa korostavat yksilöllisen asiantuntijuuden kehittymistä, ovat integratiivisessa mallissa ja verkostoituneen kulttuurin mallissa jo liikkeessä kohti yhteisöllisempää tiedonmuodostusta, ryhmämetodeja ja monitieteisten ongelmien ratkaisupyrkimyksiä jopa oppiaineiden välisessä diskurssissa. Kuvaamamme mallinnus korkeakoulujen työelämäsuhteista tarjoaa analyyttisen välineen, jonka avulla korkeakoulut, niiden yksiköt tai vaikkapa koulutusohjelmat voivat tarkastella omaa toimintaansa rakenteiden, pedagogiikan sekä opetuksen, oppimisen, ohjauksen ja opiskelijoiden hyvinvoinnin edistämisen välisten suhteiden näkökulmasta.

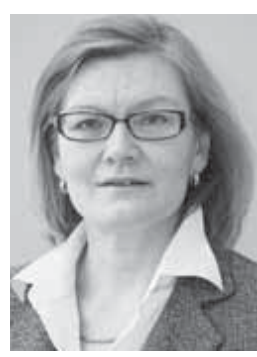

Seija Nykänen

$K T$, rehtori

Vaajakosken koulu

Jyväskylän kaupunki

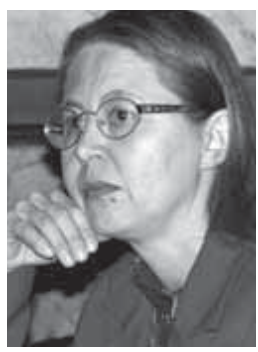

Päivi Tynjälä

professori

Koulutuksen tutkimuslaitos

Jyväskylän yliopisto

\section{LÄHTEET}

Ballantine, J. \& McCourt Larres, J. (2007). Cooperative learning: a pedagogy to improve students' generic skills? Education + Training, 49(2), 126-137.

Braun, V. \& Clarke, V. (2006). Using thematic analysis in psychology. Qualitative Research in Psychology 3, 77-101.

Barnett, R. (2004). Learning for the unknown future. Higher Education Research \& Development, 23(3). 247-260.

Barrie, S. C. (2007). A conceptual framework for the teaching and learning of generic graduate attributes. Studies in Higher Education, 32(4), 439-458.

Bereiter, C., \& Scardamalia, M. (2003). Learning to work creatively with knowledge. Teoksessa de Corte, E. Verschaffel, L., Entwistle, N. \& Merriënboer J.V. (Eds.), Powerful learning environments: Unravelling basic components and dimensions. Amsterdam: Elsevier, 55-68.

Crebert, G., Bates, M., Bell, B., Patrick, C-J. \& Cragnolini, V. (2004). Ivory tower to concrete jungle revisited. Journal of Education and Work 17(1), 47-70.

Collin, K. \& Paloniemi, S. (2007) (toim.) Aikuiskasvatus tieteenä ja toimintakenttinä. Jyväskylä: PS-kustannus.
European Qualifications Framework. (2008). Saatavilla www-muodossa: $\leftarrow U R L$ : http://ec.europa.eu/ education/lifelong-learning-policy/doc44_en.htm. $\rightarrow$ (Luettu 23.5.2011).

Framework of Qualifications for the European Higher Eduation Area. (2005). Saatavilla wwwmuodossa: $<U R L$ : http://www.ond.vlaanderen. be/hogeronderwijs/bologna/documents/ $\rightarrow$ (Luettu 23.5.2011).

Gilbert, R., Balatti, J., Turner, P. \& Whitehouse, H. (2004). The generic skills debate in research higher degrees. Higher Education Research \& Development, 23(3), 375-388.

Guile, D., \& Griffiths, T. (2001). Learning through work experience. Journal of Education Education and Work, 14(1), 113-131.

Hakkarainen, K., Lonka, K. \& Lipponen, L. (2004) Tutkiva oppiminen. Järki, tunteet ja kulttuuri oppimisen sytyttäjinä. WSOY.

Heikkinen, H., Tynjälä, P. \& Kiviniemi, U. (2011). Integrative pedagogy in practicum. Meeting the second order paradox of teacher education. Teoksessa M.Mattson, T.V. Eilertsen, \& D. Rorrison (eds). A practicum turn in teacher education. Rotterdam: Sense, 91-112. 
Jones, A. (2009). Redisciplining generic attributes: The disciplinary context in focus. Studies in Higher Education $34,85-100$.

Kallioinen, 0. (2010). Defining and comparing generic competences in higher education. European Educational Research Journal, 9(1), 56-68.

KOM. (2005). 330. Communication from the Commission to the Council and the European Parliament of 20 July 2005 - Common Actions for Growth and Employment: The Community Lisbon Programme Saatavilla wwwmuodossa: <URL: http://europa.eu/legislation_ summaries/employment_and_social_policy/community_ employment_policies/c10528_en.htm (Luettu 23.5.2011).

Kember, D. Leung, D.Y.P. \& Ma, R. (2007). Characterizing learning environments cabable of nurturing generic capabilities in higher education. Research in Higher Education, 48(5), 609-632.

Kreber, C. (2006). Setting the Context: The Climate of University Teaching. New Direction for Higher Education 133, Spring 2006, 5-11.

Knapper, C., \& Cropley, A. (2001). Lifelong learning in higher education ( ${ }^{\text {rd }}$ ed.). London: Kogan Page.

Koulutus ja tutkimus 2007-2012. (2007). Kehittämissuunnitelma. Opetusministeriö.

Lonka, K. \& Paganus, N. (2004). Ongelmalähtöinen oppiminen työelämään valmentajana. Teoksessa Tynjälä, P., Välimaa, J. \& Murtonen, M. (toim.) Korkeakoulutus, oppiminen ja työelämä. Pedagogisia ja yhteiskuntatieteellisiä näkökulmia. Jyväskylä: PSkustannus, 237-254.

Murtonen, M. Olkinuora, E. Tynjälä, P. \& Lehtinen, E. (2008). Do I need research skills in working life? University students' motivation and difficulties in quantitative methods courses. Higher Education, 56(5), 599-612.

Niiniluoto, I. (2011). Dynaaminen sivistysyliopisto. Helsinki: Gaudeamus.

Nykänen, S. (2010). Ohjauksen palvelujärjestelyjen toimijoiden käsitykset johtamisesta ohjausverkostossa - matkalla verkostojohtamiseen? Jyväskylän yliopisto. Koulutuksen tutukimuslaitos. Tutkimuksia 25. Väitöskirja.

OECD. (2011). The Assessment of Higher Education Learning Outcomes. Saatavilla www-muodossa: $\leftarrow$ URL: http://www.oecd.org/document/51/0,3343. en_2649_35961291_40119475_1_1_1_1,00.html ecd $\rightarrow$ (Luettu 23.5.2011).

OPM. (2009). Tutkintojen ja muun osaamisen kansallinen viitekehys. Opetusministeriön työryhmämuistioita ja selvityksiä 2009:24. Saatavilla www-muodossa: $<U R L$ http://www.minedu.fi/OPM/Julkaisut/2009/Tutkintojen_ kansallinen_viitekehys.html $\rightarrow$ (Luettu 23.5.2011).

Rychen, D.S. \& Salganik, L.H. (Eds.)(2003). Key competencies for successful life and well-functioning society. Cambridge, MA: Hogrefe \& Huber.

Sarja, A. (2004). Työelämäpainotteisia opetuskokeiluja yliopistoissa. Teoksessa Teoksessa Tynjälä, P., Välimaa, J. \& Murtonen, M. (toim.) Korkeakoulutus, oppiminen ja työelämä. Pedagogisia ja yhteiskuntatieteellisiä näkökulmia. Jyväskylä: PS-kustannus, 275-294.
Stenström, M-L. (2006). Polytechnic graduates working-life skills and expertise. Teoksessa Tynjälä, P., Välimaa, J. \& Boulton-Lewis, G. 2006. Higher education and working life. Collaborations, confrontations and challenges. Amsterdam: Elsevier, 89-102.

Teichler, U. (2007). Does higher education matter? Lessons from a comparative graduate survey. European Journal of Education, 42(1), 11-34

Tynjälä, P. (2008). Perspectives into learning at the workplace. Educational Research Review, 3(2), 130-154.

Tynjälä, P. (2010). Asiantuntijuuden kehittämisen pedagogiikkaa. Teoksessa Collin, K. Paloniemi, S., Rasku-Puttonen, H. \& Tynjälä, P. (toim.) Luovuus, oppiminen ja asiantuntijuus. Helsinki: WSOYpro, 79-95.

Tynjälä, P., Heikkinen, H., \& Kiviniemi, U. (2011). Integratiivinen pedagogiikka opetusharjoittelussa. Kasvatus, 148(4), 302-315.

Tynjälä, P., Pirhonen, M., Vartiainen, T., \& Helle, L. (2009). Educating IT project managers through project-based learning: A working-life perspective. The communications of the association for information systems, 24(1), 270-288.

Tynjälä, P., Slotte, V., Nieminen, J., Lonka, K., \& Olkinuora, E. (2006). From university to working life: Graduates' workplace skills in practice. Teoksessa Tynjälä, P., Välimaa, J. \& Boulton-Lewis, G. (Eds.), Higher education and working life: Collaborations, confrontations and challenges. Amsterdam: Elsevier, 73-88.

UNESCO. (1998). World declaration on higher education for the twenty-first century: vision and action. Saatavilla www-muodossa: <URL: http://www.unesco.org/ education/educprog/wche/declaration_eng.htm $\rightarrow$ (Luettu 13.5.2011).

Ursin, J. \& Hyytinen, H. (2010). Mitä korkeakoulutuksessa opitaan? Esimerkkinä AHELO. Teoksessa R. Laukkanen (toim.) PISA, PIAAC, AHELO. Miksi ja miten OECD mittaa osaamista? Opetus- ja kulttuuriministeriön julkaisuja $17 / 2010$.

Virolainen, M. (2004). Työhön sopeutumisesta oppimisen tilanteiden luomiseen. Ammattikorkeakoulujen työelämäjaksot ja työstä oppimisen mallit. Teoksessa Tynjälä, P., Välimaa, J. \& Murtonen, M. (toim.) Korkeakoulutus, oppiminen ja työelämä. Pedagogisia ja yhteiskuntatieteellisiä näkökulmia. Jyväskylä: PSkustannus, 213--233.

Virtanen, A. \& Tynjälä, P. (2011). Developing generic skills in university: a pedagogical perspective. Posteri Nordic Association for Educational Research (NERA) -konferenssissa 10-12.3 2010, Jyväskylä.

Virtanen, A., Tynjälä, P. \& Eteläpelto, A. (2011). What factors promote vocational students' learning at work. Käsikirjoitus.

Artikkeli saapui toimitukseen 27.5.2011. Se hyväksyttiin julkaistavaksi toimituskunnan kokouksessa 3.10.2011. 